\title{
위 신경초종
}

\section{김대현}

이앤김연합내과

\section{Gastric Neurilemmoma}

\section{Dae Hyun Kim}

Lee \& Kim Union Internal Medicine Clinic, Daegu, Korea

Neurilemmoma is a benign, slow-growing neoplasm originating in any nerve that has a Schwann cell sheath. They rarely occur in the digestive tract, but when they do, the most common site is the stomach. And they represent $0.2 \%$ of all gastric tumors. Because gastric neurilemmoma are usually covered by intact mucosa and mainly involve the submucosal and muscularis propria, they are categorized as gastric submucosal tumor. Although endoscopic examination is important in the initial evaluation of a gastric SET, they cannot provide enough information in the differential diagnosis of a gastric submucosal tumor. Transabdominal ultrasonogrphy provides useful information regarding the layer of origin, the size of the lesion, morphologic features, differential diagnosis and follow up of gastric submucosal tumor. Author report a case of gastric neurilemmoma presenting as a gastric submucosal tumor in a 65-year-old male patient.

Keywords: Neurilemmoma; Stomach; Submucosal tumor; Ultrasonography

\section{서 론}

신경초종(neurilemmoma)은 신경집 세포에서 기원하는 양성 종양으로 위장관에서는 위에서 가장 높은 빈도로 발생하나 전체 위 종양의 $0.2 \%$ 를 차지하는 매우 휘귀한 질환이다. 대부분 무 증상이지만 간혹 복통, 복부 불쾌감, 상부 위장관 출혈 등의 증 상을 보이기도 한다. 내시경 소견은 위 상피내 병변으로 관찰되 어 위 간엽성 종양인 위장관간질성종양(gastrointestinal stromal tumor, GIST)과 평활근 종양(leiomyoma)과의 감별이 어려워 병 리학적인 소견이 진단에 중요하다.

저자는 수개월 전부터 지속된 소화불량과 상복부 통증을 주
소로 내원한 65세 남자 환자에서 위내시경검사와 복부 초음파 검사 결과 위 상피하 종양이 의심되어 수술적 치료를 시행, 위 신경초종으로 진단된 증례를 초음파 소견과 병리학적인 소견을 중심으로 보고하는 바이다.

\section{증 례}

65세 남자가 2달 전부터 지속된 재발되는 상복부 통증과 복부 불쾌감을 주소로 내원하였다. 내원 당시 혈압은 $130 / 86 \mathrm{mmHg}$ 였고 맥박 75 회/분, 호흡수 20회/분, 체온 36.3도였다. 신체검사 에서 특별한 이상 징후는 없었다. 말초혈액검사에서 혈색소
Address for Correspondence: Dae Hyun Kim, M.D., Ph.D.

Lee \& Kim Union Internal Medicine Clinic, 2 Yulhadong-ro 23-gil, Dong-gu, Daegu 41119, Korea

Tel: +82-53-964-3370, Fax: +82-53-964-3372

E-mail: pylori@empas.com
Received : 2018. 10. 9

Revised : 2018.11. 6

Accepted: 2018. 11. 8 
$15.2 \mathrm{~g} / \mathrm{dL}$, 백혈구 $5,270 / \mathrm{mm}^{3}$ (중성구 49.6\%, 림프구 $33.5 \%$, 단 핵구 $8.1 \%$, 호산구 $4 \%$ ), 혈소판 $296,000 / \mathrm{mm}^{3}$ 였으며 생화학검사 에서 aspartate transaminase $23 \mathrm{U} / \mathrm{L}$, alanine transaminase 20 $\mathrm{U} / \mathrm{L}$, glutamyl transferase $42 \mathrm{U} / \mathrm{L}$, alkaline phosphatase $62 \mathrm{U} / \mathrm{L}$, 총 단백/알부민 7.2/4.3 g/dL였고 blood urea nitrogen $12.7 \mathrm{mg} / \mathrm{dL}$, creatinine $0.58 \mathrm{mg} / \mathrm{dL}$, amylase $64 \mathrm{U} / \mathrm{L}$, lipase $47 \mathrm{U} / \mathrm{L}$ 였고 공복 혈당 64였고 PT, aPTT 및 요검사에서 정상 소견이었다.

상부내시경검사에서 하체부 전벽에 표면이 매끄러운 점막하 병변이 관찰되었고 내시경 겸자로 압박시 단단한 느낌이었 다(Fig. 1).

환자에게 물을 $400 \mathrm{~mL}$ 섭취하게 한 후 시행한 복부 초음파검 사(Acuson S1000, Siemens, Erlangen, Germany)에서 위하체부 전벽에 변연은 비교적 매끄러운 타원형의 불균질한 고형성의 저 에코성 종양이 고유근층에 관찰되었고 이는 간의 좌엽과 인접 해 있어서 간좌엽에서 외부로 돌출하는 간 종양과 감별이 필요
하였다(Fig. 2A and 2B). 내부에 부분적으로 고에코 병변이 관 찰되었으나 석회화 및 낭성병변은 관찰되지 않았다. 색도플러검 사에서 종양의 내부에 혈류증가 소견은 없었고, 변연에 경미한 혈류신호가 관찰되었다(Fig. 2 C). 종양의 크기는 $4.6 \times 4.9 \mathrm{~cm}$ 였고 4층인 고유근층에 국한되어 위에 발생하는 가장 흔한 위 장관간엽종양인 GIST를 의심할 수 있었으나 크기에 비하여 종 양 내부에 낭성 변화나 변성 소견이 없어 신경종양 또는 평활근 종도 감별이 필요하였다.

복부 전산화단층촬영(computed tomography, CT)검사에서 위 체부의 전벽에 약 $5 \mathrm{~cm}$ 크기의 균질하게 조영증강되는 종괴가 관찰되었다(Fig. 3). 정확한 진단을 위하여 초음파내시경검사 및 초음파내시경 유도하 세침흡인생검을 위하여 3차병원으로 전원 하였다. 3 차병원에서 시행한 초음파내시경검사에서 하체부 전벽 에 $5 \mathrm{~cm}$ 크기의 비교적 균질한 고형성의 저에코 종양이 4층인 고유근층에 있었고 초음파내시경 유도하 세침흡인생검과 조직
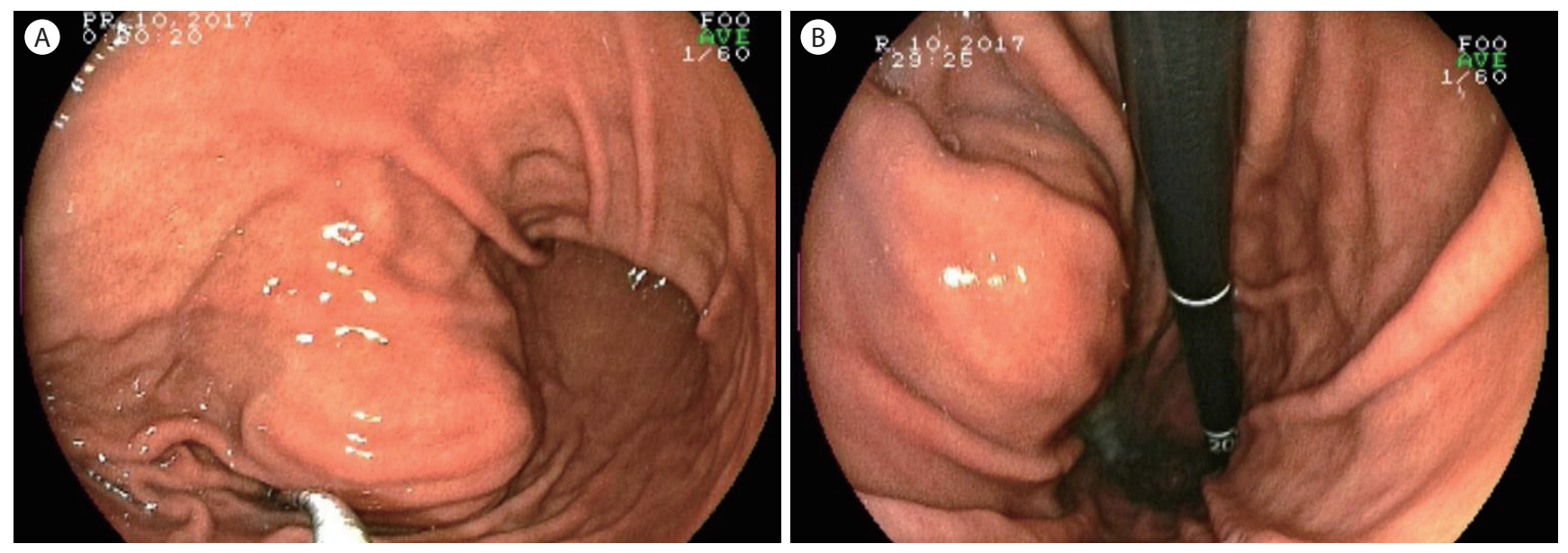

Figure 1. Upper endoscopy (A, B). Endoscopy showed about $5 \mathrm{~cm}$ sized submucosal lesion with smooth surface at anterior wall of distal body.
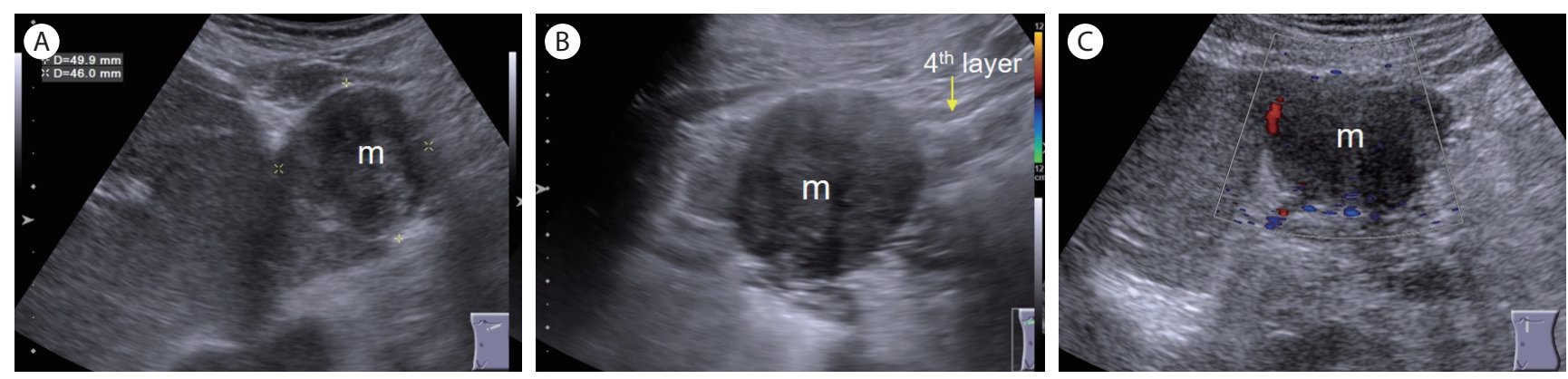

Figure 2. Transabdominal ultrasonography. (A, B) Trandabdominal ultrasonography obtained with 4-MHz convex transducer showing a well demarcated, slightly heterogenous, hypoechoic round-shaped mass $(\mathrm{m})$ with scattered echogenic spots growing exophytically, approximately $4.6 \times 4.9 \mathrm{~cm}$ in diameter which is mainly located in the 4th layer of the anterior wall of the distal body. (C) Color doppler ultrasonography showing no increased flow within the mass. 
검사를 시행하였다. 면역조직화학 염색에서 S-100 단백에 양성, $\mathrm{SMA}$ 단백에 음성, C-kit 및 CD34, DOG-1에 음성으로 위 신경 초종으로 진단되었다.

이상으로 위 신경초종으로 진단되어 일반외과로 전원하여 복 강경하 쐐기 절제술(wedge resection)을 시행하였다. 수술 후 조 직 병리학적 소견에서 육안적으로 $4 \times 5 \mathrm{~cm}$ 크기의 경계가 뚜 렷한 종괴였다. 절단면은 백색으로 관찰되었고 점막에는 궤양이 없이 정상적인 점막으로 덮여 있었으며 외벽으로 돌출되는 양상 을 보였다(Fig. $4 \mathrm{~A}$ ). 현미경적 소견에서 고유근층에 비교적 경계 가 좋은 종괴가 있었고 종양의 외부에 림프구 덩어리가 종양의 주위를 둘러싸고 있었다. 종양의 내부에는 종양 세포들의 밀도 가 높은 곳과 낮은 곳이 교차로 나타났으며 종양 세포들의 핵은 방추형의 끝이 뾰족한 모양이었으며 세포학적 이형성 및 유사분 열은 관찰되지 않았다(Fig. $4 \mathrm{~B}$ and $4 \mathrm{C}$ ). 면역조직화학 염색에서 S-100 단백에 양성, SMA 단백에 음성, C-kit 및 CD34, DOG-1 에 음성이었다(Fig. 4D).

상기 소견들로 위에 발생한 위 신경초종으로 확진하였고 환자 는 합병증 없이 외래에서 추적 관찰 중이다.

\section{고 찰}

신경초종은 신경집 세포에서 기원하는 양성 종양으로 청각신 경에 주로 발생하고 드물게 위장관에서 발생한다[1]. 위장관 중 에서는 위에서 가장 높은 빈도로 발생하나 전체 위 종양의 $0.2 \%$ 를 차지하는 매우 휘귀한 질환이다. 위 신경초종은 위벽에 서 근육층 신경얼기(Auerbach plexus)나 마이스너 신경얼기
(Meissner's plexus)에서 기인한다[2]. 30세에서 60세 사이의 연령 대에서 발생하여 남녀의 발생비율은 비슷하다. 보통 단발성으로 발생하며 위치는 소만부를 따라서 발생하고 전정부나 유문부를 따라서 잘 발생하는 것으로 알려져 있으나 본 증례에서는 체부 의 전벽에 발생하였다. 크기는 0.5-11 cm까지 다양하며 모양은 구형 또는 타원형이다[3]. 종괴는 정상점막으로 덮여있고 점막 하층과 고유근층에 침범하며 점막하, 장막하 또는 벽내성 성장 을 한다.

대부분 무증상으로 우연히 발견되는 경우가 많으나 간혹 복 통, 복부 불쾌감과 종괴를 덮고 있는 점막의 궤양으로 인한 상 부 위장관 출혈의 증상을 보이기도 한다[1].

진단을 위해서 상부내시경검사가 중요하다. 위 신경초종은 위 점막하 종양으로 정상점막으로 덮여있어 일반적인 생검으로 조 직학적 진단이 어렵고 위 상피하 종양 중에서 비교적 흔한 질환 인 위장관간질종양 및 위평활근종과의 감별이 어렵다. 내시경검 사에서 종양의 크기가 크고 궤양이 있어 출혈이 동반된 경우 악 성의 가능성이 많아 수술적인 치료 여부를 결정할 때 중요한 역 할을 한다. 위점막하 종양의 감별진단을 위해서 위벽의 층 구조 와 내부 에코를 알 수 있는 초음파내시경검사를 최근에 많이 활 용하며 위에서 발생하는 위장관간질성 종양의 악성도를 평가하 는 기준으로 종양의 크기( $4 \mathrm{~cm}$ 이상), 종양 내부의 고에코 부위 과 낭종성 병변, 불규칙한 경계 등을 제시한 바 있다[4,5].

최근에 고해상도 초음파의 도입으로 경복부 초음파를 위점막 하 종양의 진단에 활용할 수 있다. 초음파내시경검사에 비해서 예민도가 낮고 시술자의 숙련도에 따른 진단율의 차이가 있다 는 단점이 있으나 비침습적이고 비용이 적게 들며 쉽게 접근할
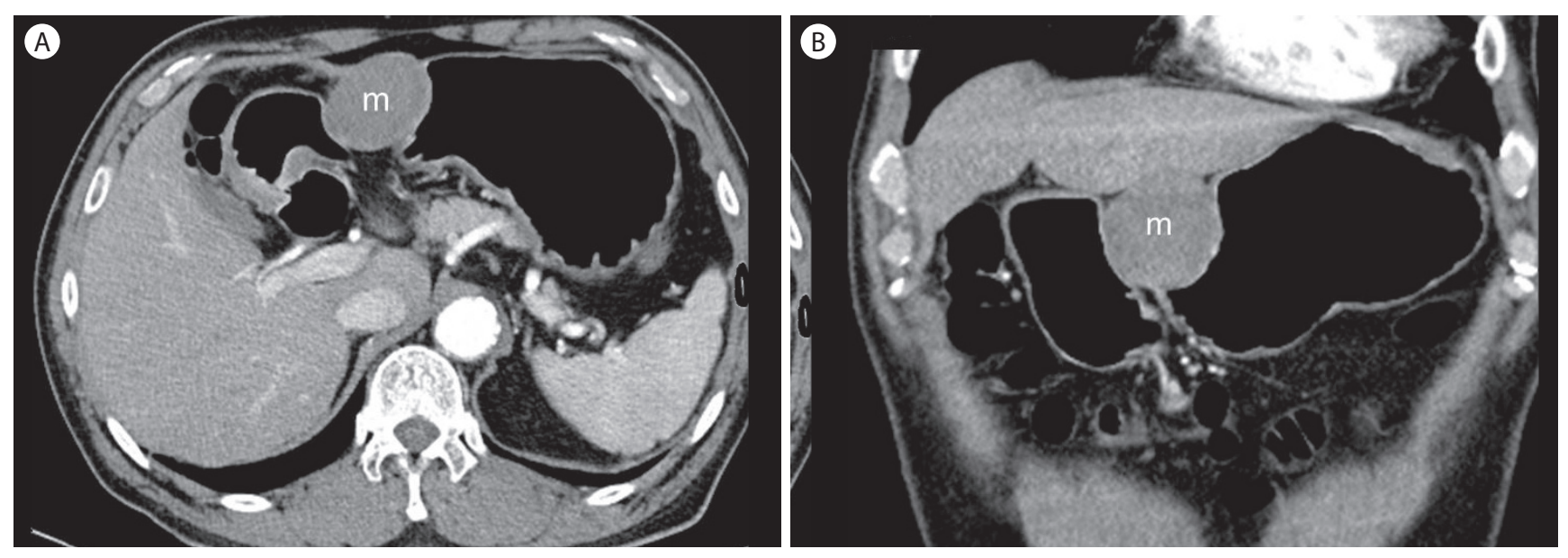

Figure 3. Computed tomography. (A, B) On the anterior wall of the gastric body, about $5 \mathrm{~cm}$ sized round exophytic mass (m) with homogenous enhancement was noted. It is covered by the intact mucosal layer. 

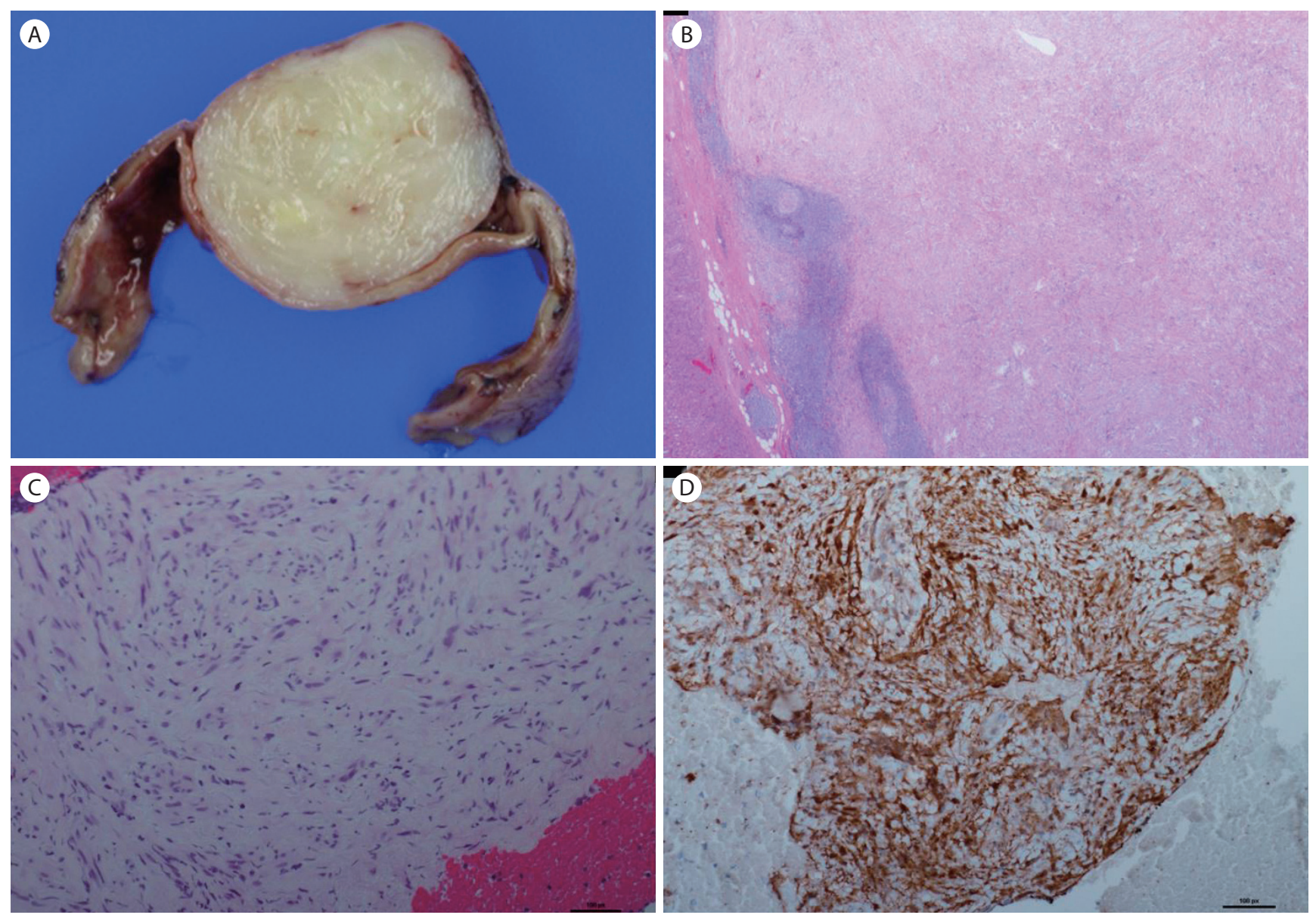

Figure 4. Pathologic findings. (A) Gross finding: round mass with normal overlying mucosa was noted. (B) Microscopic finding: on the low power examination, the tumor composed by spindle cells is seen with characteristic peritumoral lymphoid cuff. The mucosa is intact (H\&E stain, $\times 20)$. (C) Microscopic findings: the tumor cells have spindle, vesicular and wavy neuclei (H\&E stain, $\times 200)$. (D) Immunohistochemical staining for S-100 protein Tumor cells are strongly positive for S-100 protein (x100).

수 있어서 제한적으로 활용을 해 볼 수 있겠다. 위 내강을 400$500 \mathrm{~mL}$ 의 탈기수로 채우면 위 내강이 물로 충만되면서 위가 확 장되고 물이 음향창이 되어 위벽의 층 구조 및 점막하 종양의 크기, 에코 정도를 파악할 수 있다. 일반적으로 위전정부와 체 부의 병변을 비교적 잘 관찰할 수 있으나 위저부의 병변은 관찰 이 힘들다. 본 증례에서는 위내시경검사에서 병변이 위의 하체 부 전벽에 위치하였고 복부 초음파검사에서 위벽의 4층인 고유 근층에 위치한 저에코성 병변으로 잘 관찰되었다.

초음파검사에서 위벽의 고유근층에 발생하는 위점막하 종양 중 위 신경초종과 위장관간질성 종양의 감별이 중요하다. 두 질 환에서 서로 중복되는 소견이 존재하여 감별이 쉽지 않지만 위 장관간질성 종양에 비해 위 신경초종의 경우 종양의 에코밀도는 균질하고 에코가 고유근층과 비슷하거나 낮은 경우가 많은 반 면 출혈, 괴사 및 낭성 변화와 같은 변성이 흔하지 않다. 이에 비
해 위장관간질성 종양에서는 에코밀도가 불균질하고 출혈, 괴 사, 낭성 변화가 더 흔하며 $6 \%$ 에서는 석회화가 관찰된다[6].

복부 $\mathrm{CT}$ 검사에서 위 신경초종의 균질한 조영증강이 관찰되어 과혈관성 종양을 의미하나 위 신경초종 내부의 혈류 속도가 매 우 느리기 때문에 도플러검사에서는 혈류신호의 증가는 없는 것이 특징이다[7].

위 신경초종의 확진은 조직학적 검사를 통해서 할 수 있다. 광 학현미경 검사에서 방추형 세포다발을 형성하며 종양 가장자리 에 두꺼운 림프구층이 보인다. 이러한 림프구층은 종양조직에 대한 면역 반응으로 여겨지고 있다. 면역 조직학적 소견은 진단 에 있어 중요한 역할을 하며 항상 S-100 단백의 발현이 나타나 는 특징이 있다. S-100 단백항체는 신경외배엽으로부터 분화되 었음을 나타내는 표지자이다[8].

이 질환의 확진은 면역 조직화학염색 검사에서 S- 100, C-kit, 
$\mathrm{CD} 34, \mathrm{SMA}$ 에 대한 반응 여부로 할 수 있으며 위장관간질성 종 양의 경우 S-100 음성, C-kit 양성, CD34 양성, SMA 음성 소견 이 특징이며, 위 평활근종의 경우 S-100 음성, C-kit 음성, CD34 음성, SMA 양성의 소견을 보인다. 반면에 위 신경초종의 경우 에는 S-100 양성, C-kit 음성, CD34 음성, SMA 음성이 특징적 인 소견이며[9] 본 증례에서도 같은 소견을 보였다. 위장관간질 성 종양의 경우 악성의 가능성이 있지만 위평활근종과 위 신경 초종의 경우 양성 종양이다. 하지만 내시경검사와 초음파검사에 서 이 3가지 질환을 구분하는 것은 어려우므로 의심되면 적극 적으로 절제하는 것이 필요하다. 최근에는 초음파내시경 유도하 세침흡인생검 및 조직검사로 면역조직화학염색검사를 하여 S-100, C-kit, CD34, SMA에 대한 반응을 보고 무증상의 크기 가 작은 위 신경초종이나 평활근종의 경우 수술적인 치료 없이 추적검사를 할 수 있는 근거를 제공해준다.

위 신경초종의 치료는 증상이 있거나 위장관간질성 종양과 감 별이 어려운 경우 수술적 치료가 요구된다. 만약 무증상이거나 크기가 작은 경우 정기적인 검사를 하면서 관찰할 수 있겠다[10].

\section{요 약}

위 신경초종은 위장관벽의 신경집 세포에서 기원하는 천천히 자라는 간엽성 종양으로, 위 종양의 $0.2 \%$ 를 차지하는 아주 드 문 양성 종양이다. 임상적으로 대부분 무증상이나 상부 위장관 출혈과 복통을 동반하기도 한다. 상부내시경검사에서 점막하 종양으로 관찰되어 위에서 가장 흔한 간엽성 종양인 위장관간 질성 종양과 구분이 어렵다. 저자는 평소 상복부 통증과 소화 불량을 주소로 내원한 65세 남자에서 위내시경검사에서 발견된 점막하 종양에 대해 시행한 복부 초음파검사에서 고유근층에 서 발생한 위장관간질성 종양 의심하에 3차병원으로 전원하여 시행한 초음파내시경 유도하 세침흡인생검과 조직검사에서 위 신경초종으로 진단되어 복강경하 쐐기절제술로 치료하였던 증
례를 보고하는 바이다.

중심 단어: 신경초종; 위; 점막하 종양; 초음파

\section{REFERENCES}

1. Rew JS, Choi SK, Yoon KH, et al. A case of neurilemoma originated in the stomach. Korean J Gastroenterol 1990;22:961-967.

2. Hwang JH, Kimmey MB. The inciedental upper gastrointestinal subepithelial mass. Gastroenterology 2004;126:301-307.

3. Park HC, Kim BW, Lee JC. The neurilemmoma of the stomach: a case report. J Korean Surg Soc 1992;42:862-866.

4. Chak A, Canto M, Rösh T, et al. Endosonographic differentiation of benign and malignant stromal cell tumors. Gastrointest Endosc 1997;45:468-473.

5. Park HC, Son DJ, Oh HH, et al. Endoscopic ultrasonographic characteristics of gastric schwannoma distinguished from gastrointestinal stromal tumor. Korean J Gastroenterol 2015;65:2126.

6. Kwon MS, Lee SS, Ahn GH. Schwannomas of the gastrointestinal tract: clinicopathological features of 12 cases including a case of esophageal tumor compared with those of gastrointestinalstromal tumors and leiomyomas of the gastrointestinal tract. Pathol Res Pract 2002;198:605-613.

7. Zhong DD, Wang CH, Xu JH, Chen MY, Cai JT. Endoscopic ultrasound features of gastric schwannomas with radiological correlation: a case series report. World J Gastroenterol 2012;18:7397-7401.

8. Melvin WS, Wilkinson MC. Gastric schwannoma. Clinical and pathologic considerations. Am Surg 1993;59:293-296.

9. Miettinen M, Virolainen M, Maarit-Sarlomo-Rikala. Gastrointestinal stromal tumors--value of CD 34 antigen in their identification and separation from true leiomyomas and schwannomas. Am J Surg Pathol 1995;19:207-216.

10. Davila RE, Faigel DO. Gl stromal tumors. Gastrointest Endosc 2003;58:80-88. 